\title{
DOŚWIADCZENIA POLSKIE W MINIMALNYM OPODATKOWANIU: PODATEK OD PRZYCHODÓW Z BUDYNKÓW
}

\section{Marcin Jamroży ${ }^{*}$ Aleksander Łożykowski* \\ POLISH ENCOUNTER WITH A MINIMUM TAXATION: \\ REVENUE TAX ON COMMERCIAL BUILDINGS}

\begin{abstract}
The purpose of the article/hypothesis. The purpose of the article is to present the concept of the minimum tax on revenues from commercial buildings and to evaluate the regulation introduced, including the formulation of de lege ferenda postulates.

Methodology. The regulatory evolution of the tax structure in 2018-2020 was analyzed and its impact on taxpayers' settlements.

Results of the research. The hypothesis that the minimum tax in the form of a tax on revenues from commercial buildings is a non-excessive anti-abusive measure is verified. One of the purposes of this tax is, in particular, to prevent tax avoidance and profit shifting by large real estate companies owning commercial real estate of significant value. Only about $1 / 3$ of taxpayers did not fully deduct the minimum tax due on commercial buildings from the corporate income tax calculated on general basis. The effect of the increased tax burden, at least temporarily, is mitigated by a number of solutions securing the neutrality of this tax and a relatively low level of the minimum tax.
\end{abstract}

Keywords: minimum tax, revenue taxation, commercial buildings, tax avoidance, real estate companies.

JEL Class: H22, H25, H26.

\footnotetext{
* Dr hab., Prof. SGH, Instytut Finansów, Szkoła Główna Handlowa w Warszawie; https://orcid.org/0000-0003-0536-3364.

** Mgr, Instytut Finansów, Szkoła Główna Handlowa w Warszawie; https://orcid.org/0000-0002-7349-5302.
} 


\section{WSTĘP}

Koncepcja opodatkowania minimalnego jest znana i stosowana w wielu jurysdykcjach podatkowych (Shaviro, 2020: 2-21). Na poziomie międzynarodowym prowadzone są prace nad wprowadzeniem globalnej minimalnej stawki podatku dochodowego dla osób prawnych dla przedsiębiorstw gospodarki cyfrowej lub cyfryzującej się. Taka minimalna stawka podatkowa ma na celu przeciwdziałanie czerpaniu korzyści z podatkowo motywowanego przeniesienia działalności do jurysdykcji cechujących się niskim poziomem opodatkowania. Na przykład, jeżeli globalna minimalna stawka podatku wynosi $12 \%$, a państwo źródła (raj podatkowy) stosuje stawkę 5\%, to państwo rezydencji będzie mogło nałożyć podatek w wysokości 7\% (OECD/G20, 2020).

W polskim ustawodawstwie podatkowym tzw. minimalny podatek dochodowy już funkcjonuje $\mathrm{w}$ formie tzw. podatku od przychodów $\mathrm{z}$ budynków położonych na terytorium Polski i został wprowadzony począwszy od 2018 roku (zob. art. 2 pkt 27) ustawy z dnia 27 października 2017 r.). Koncepcja polskiego podatku minimalnego od nieruchomości komercyjnych wiąże go z posiadaniem aktywów o relatywnie wysokiej wartości. Podatek ten ma w szczególności zapobiegać unikaniu opodatkowania poprzez niewykazywanie dochodu przez duże spółki nieruchomościowe, posiadające nieruchomości komercyjne o znacznej wartości (zob. Uzasadnienie do rządowego projektu ustawy...: 31-33). Celem przyjętej formuły minimalnego opodatkowania przychodów z nieruchomości komercyjnych jest zapewnienie efektywnego opodatkowania uzyskiwanego przez podatników inwestujących $\mathrm{w}$ nieruchomości komercyjne zwrotu z takiej inwestycji. W założeniu podatkiem powinni zostać objęci podatnicy, którzy poprzez stosowanie instrumentów tzw. agresywnej optymalizacji podatkowej, płacą niski podatek dochodowy (na zasadach ogólnych) bądź w ogóle go nie uiszczają. Podatek minimalny od nieruchomości komercyjnych wyznacza zatem minimalny poziom podatku dochodowego, który podatnik jest obowiązany zapłacić w ciągu roku podatkowego.

Zasadniczym celem artykułu jest przedstawienie koncepcji i mechanizmu działania podatku minimalnego od nieruchomości komercyjnych oraz dokonanie oceny wprowadzonej regulacji, w tym sformułowanie postulatów de lege ferenda. Podatek minimalny od nieruchomości komercyjnych płacony jest przede wszystkim przez podatników podatku dochodowego od osób prawnych (CIT). Podatnicy PIT mają relatywnie niewielkie znaczenie, odpowiadając za nie więcej niż $10 \%$ wpływów z podatku minimalnego w ujęciu łącznym (PIT i CIT) ${ }^{1}$. Z tych względu uwaga autorów zostanie skupiona zasadniczo na podatnikach CIT.

Stawia się hipotezę, że podatek minimalny w formie podatku od przychodów $\mathrm{z}$ budynków jest nienadmiarowym środkiem antyabuzywnym.

${ }^{1}$ Zob. poniżej tabela 1: Statystyki dotyczące minimalnego podatku od nieruchomości komercyjnych. 


\section{EWOLUCJA PODATKU MINIMALNEGO OD PRZYCHODÓW Z BUDYNKÓW}

W pierwotnym kształcie podatek minimalny od nieruchomości komercyjnych dotyczył jedynie określonych kategorii środków trwałych - budynków biurowych oraz niektórych budynków handlowo usługowych, w tym przede wszystkim centrów handlowych. Opodatkowaniu nie podlegały budynki biurowe wykorzystywane wyłącznie lub w głównym stopniu na własne potrzeby podatnika. Podstawę opodatkowania stanowił przychód odpowiadający wartości początkowej środka trwałego ustalanej na pierwszy dzień każdego miesiąca wynikającej z prowadzonej ewidencji, pomniejszonej o kwotę $10 \mathrm{mln}$ zł. Kwota wolna od podatku odnosiła się do każdej nieruchomości podatnika odrębnie, a nie do łącznej wartości wszystkich nieruchomości podatnika objętych obowiązkiem podatkowym. W konsekwencji opodatkowane były jedynie ustawowe przychody z największych nieruchomości budynkowych podatników. Podatnicy obowiązali byli podatek obliczać i wpłacać za każdy miesiąc, mogli go jednak odliczać w ciągu roku od zaliczek na podatek dochodowy względnie od należnego podatku za cały rok podatkowy. Podatnicy nie musieli uiszczać podatku minimalnego w ogóle, jeśli był on mniejszy niż kwota wpłaconych zaliczek na podatek dochodowy.

Niektóre regulacje dotyczące podatku od nieruchomości komercyjnych były przedmiotem postępowania przed Komisją Europejską która badała, czy nie stanowią one niedozwolonej pomocy publicznej. Podstawowym zarzutem Komisji było możliwe naruszenie zasad konkurencji poprzez objęcie podatkiem jedynie wąskiej grupy podatników (Banasik i in., 2018). W wyniku konsultacji Ministerstwa Finansów z Komisją Europejską, wypracowano rozwiązania, które mają zapewniać zachowanie zasad równej konkurencji i udzielania pomocy publicznej (Ministerstwo Finansów, 2018).

Zmiany te polegały na:

- rozszerzeniu zakresu przedmiotowego podatku na przychody zasadniczo ze wszystkich budynków,

- objęciu opodatkowaniem tylko przychodów z budynków, które zostały w całości lub części oddane do używania, bez względu na kategorię budynku,

- odejściu od pomniejszania wartości poszczególnych budynków o kwotę wolną i odniesieniu tej kwoty jednorazowo do całej podstawy opodatkowania minimalnym podatkiem od nieruchomości komercyjnych,

- wprowadzeniu instytucji zwrotu podatku minimalnego w razie niestwierdzenia przez organ nieprawidłowości w rozliczeniu podatku dochodowego,

- wprowadzeniu szczególnej klauzuli przeciwko unikaniu opodatkowania podatkiem minimalnym od nieruchomości komercyjnych.

Rozwiązaniom korzystnym dla podatników polegającym na ograniczeniu opodatkowania tylko do przychodów z części budynków oddanych do używania (zob. art. 6 ustawy z dnia 15 czerwca 2018 r. ...) oraz możliwości wnioskowania 
o zwrot podatku (zob. art. 5 ustawy z dnia 15 czerwca 2018 r. ...) nadano moc wsteczną (dotyczą rozliczeń podatkowych także za 2018 rok). Zmiany niekorzystne z punktu widzenia podatników, czyli przede wszystkim rozszerzenie przedmiotu opodatkowania na przychody z innych kategorii budynków oraz zawężenie zastosowania kwoty wolnej mają zastosowanie od rozliczenia za rok 2019. Zawężenie podstawy opodatkowania za 2018 rok w wyniku wprowadzonych zmian należy mieć na uwadze przy dokonywaniu oceny wpływów sektora finansów publicznych z tytułu podatku minimalnego.

\section{PODSTAWOWE ELEMENTY KONSTRUKCYJNE PODATKU MINIMALNEGO}

Przedmiotem opodatkowania jest przychód z wszystkich budynków (mieszkalnych i niemieszkalnych) bez względu na ich klasyfikację. Budynki muszą spełniać następujące kryteria:

a) stanowić własność lub współwłasność podatnika,

b) być położone na terytorium Polski oraz

c) być oddane do używania w całości lub w części na podstawie umowy najmu, dzierżawy lub innej umowy o podobnym charakterze.

Przychód jest określony jako ustalona na pierwszy dzień każdego miesiąca wartość początkowa podlegającego opodatkowaniu środka trwałego wynikająca $\mathrm{z}$ prowadzonej ewidencji, a w miesiącu, w którym środek trwały został wprowadzony do ewidencji - wartość początkowa ustalona na dzień wprowadzenia środka trwałego do ewidencji.

Zwolnieniu z podatku podlegają budynki mieszkalne oddane do używania w ramach realizacji programów rządowych i samorządowych dotyczących budownictwa społecznego. Wyłączone z opodatkowania zostały również budynki, których łączny udział oddanej do używania innym podmiotom powierzchni użytkowej budynku nie przekracza 5\% całkowitej powierzchni użytkowej tego budynku (zob. art. 24b ust. 7 ustawy z dnia 15 lutego 1992 r. ...). Oznacza to, że zwolnione z podatku są budynki wykorzystywane przynajmniej w 95\% we własnej działalności gospodarczej.

W przypadku budynków oddanych do używania tylko częściowo, do kalkulacji podstawy opodatkowania brana pod uwagę jest wartość budynku ustalona proporcjonalnie do udziału powierzchni użytkowej oddanej do użytku w całkowitej powierzchni użytkowej tego budynku. Podobnie postępuje się w przypadku znajdujących się w budynku lokali mieszkalnych oddanych do używania w ramach realizacji programów rządowych i samorządowych dotyczących budownictwa społecznego.

Podstawę opodatkowania stanowi suma przychodów z budynków z poszczególnych budynków, pomniejszona o kwotę $10 \mathrm{mln}$ zł (zob. art. 24b ust. 9 ustawy 
z dnia 15 lutego 1992 r. ...). W poprzednim stanie prawnym kwota wolna w wysokości $10 \mathrm{mln}$ zł dotyczyła każdego budynku odrębnie. Ocenie każdemu podatnikowi przysługuje kwota wolna w tej samej wysokości. Ustalenie jednej kwoty wolnej dla wszystkich budynków należących do podatnika ogranicza pole do unikania opodatkowania, np. poprzez dzielenie środka trwałego na mniejsze w celu obniżenia jednostkowej wartości początkowej poniżej progu $10 \mathrm{mln}$ zł (Banasik i in., 2018). Stawka podatku wynosi $0,035 \%$ podstawy opodatkowania za każdy miesiąc.

Wprowadzono szczególny sposób określania podstawy opodatkowania w przypadku podmiotów powiązanych kapitałowo. Jeżeli podatnik posiada minimum 25\% udział w kapitale innego podmiotu, kwotę wolną, ustala się w takiej proporcji, w jakiej suma wartości poszczególnych budynków, pozostaje do ogólnej kwoty sumy wartości poszczególnych budynków grupy kapitałowej (podatników powiązanych) (zob. art. 24b ust. 10 ustawy z dnia 15 lutego 1992 r. ...). Nie jest możliwe, by kwota wolna w przypadku podmiotów powiązanych przekroczyła $10 \mathrm{mln}$ zł łącznie ${ }^{2}$, co oznacza to, że kwota $10 \mathrm{mln}$ zł jest górnym limitem dla całej grupy kapitałowej. Należy uznać, że wydzielenie z nieruchomości budynkowych odrębnych środków trwałych (np. windy) wpływa minimalizująco na rozliczenie podatnika z tytułu podatku od przychodów z budynków. Niższa wartość początkowa budynku prowadzi do obniżenia należnego minimalnego podatku.

Stawka podatku wynosi $0,035 \%$ podstawy opodatkowania za każdy miesiąc.

Podatek od przychodów z budynków jest płacony za każdy miesiąc i nie ma charakteru zaliczki na poczet podatku dochodowego. Kwota podatku od przychodów z budynków nieodliczona od daniny płaconej na zasadach ogólnych podlega zwrotowi na wniosek podatnika, jeżeli organ nie stwierdzi nieprawidłowości wysokości zobowiązania podatkowego lub straty w złożonym zeznaniu (zob. art. 24b ust. 15 ustawy z dnia 15 lutego 1992 r. ... i art. 30g ust. 15 ustawy z dnia 26 lipca 1991 r. ...). Możliwość ubiegania się o zwrot dotyczy również podatku minimalnego zapłaconego przed dniem 1 stycznia 2019 r. Warto zauważyć, że w wyniku kolejnych tarcz antykryzysowych (Dz.U. 2020, poz. 374; Dz.U. 2020, poz. 1086; Dz.U. 2020, poz. 2123) początkowo przesunięto termin zapłaty podatku minimalnego od nieruchomości komercyjnych, ostatecznie zwalniając podatników z tego podatku w ogóle do końca miesiąca, w którym stan epidemii zostanie odwołany.

Przepisy o podatku od przychodów z budynków zostały wzbogacone o klauzulę antyabuzywną TAAR (Targeted Anti-Avoidance Rule). Regulacje dotyczące podatku minimalnego stosuje się również w przypadku, gdy podatnik, bez uzasadnionych przyczyn ekonomicznych, przeniesie w całości lub w części własność lub współwłasność budynku (albo odda do używania w ramach umowy leasingu)

${ }^{2}$ Podejście takie potwierdza interpretacja indywidualna DKIS z dnia 11 marca 2019 r., [sygn. 0111-KDIB2-1.4010.512.2018.1.MJ]. 
W celu uniknięcia podatku od przychodów z budynków (zob. art. 24b ust. 18 ustawy z dnia 15 lutego 1992 r. ...).

Algorytm ustalania zobowiązania podatkowego z tytułu podatku minimalnego od przychodów z budynków można ująć w postaci schematu składającego się z czterech elementów (rysunek 1).

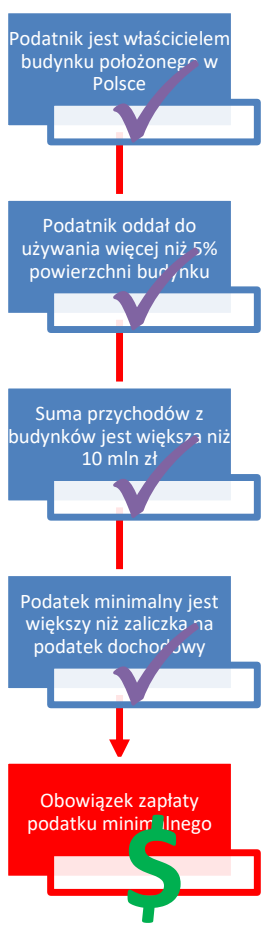

Rys. 1. Schemat ustalania zobowiązania z tytułu podatku od przychodów z budynków.

Źródło: opracowanie własne.

\section{STRUKTURA WPŁYWÓW Z TYTUŁU PODATKU MINIMALNEGO}

Podatek minimalny od przychodów z budynków obowiązuje w Polsce już trzeci rok. Z uwagi na szczególne rozwiązania wprowadzone w roku 2020 związane $\mathrm{z}$ epidemią koronawirusa ( $\mathrm{w}$ tym ostatecznie zwolnienie $\mathrm{z}$ podatku minimalnego), pod uwagę wzięte zostały dane na temat rozliczenia tego podatku jedynie za 2018 i 2019 r. Ze względu na znaczne różnice w zakresie podmiotowym i przedmiotowym opodatkowania w 2018 i 2019 r. dane te nie są wprost porównywalne i wyrażają $\mathrm{w}$ większym stopniu wpływ zmian regulacyjnych niż sytuacji ekonomicznej podatników na przestrzeni tych lat. 
Podatek minimalny od nieruchomości komercyjnych jest podatkiem ze swojej istoty ukierunkowanym na wąskie grono podatników, którzy posiadają nieruchomości o znaczącej wartości i oddają je do używania innym podmiotom. Nie dziwi więc, że w 2018 r. podatek od przychodu ze środka trwałego wykazało zaledwie 2591 podatników CIT, a w 2019 r. 3551 podatników CIT. Oznacza to, że niecały $1 \%$ wszystkich podatników CIT zostało objętych tym podatkiem. Zdecydowana większość podatników podatku minimalnego od nieruchomości komercyjnych to spółki kapitałowe, ale wśród podatników znalazło się także kilkaset wspólnot mieszkaniowych oraz pewna reprezentacja spółdzielni, stowarzyszeń, fundacji i podobnych podmiotów ${ }^{3}$.

Podstawowe statystyki dotyczące podatku minimalnego od nieruchomości komercyjnych w Polsce dotyczące podatników CIT w latach 2018 i 2019 zawarto w tabeli 1 i na wykresie 1. Zebrane dane obrazują przede wszystkim liczbę podatników tego podatku w poszczególnych latach, kwotę zapłaconego podatku oraz kwotę nieodliczonego podatku.

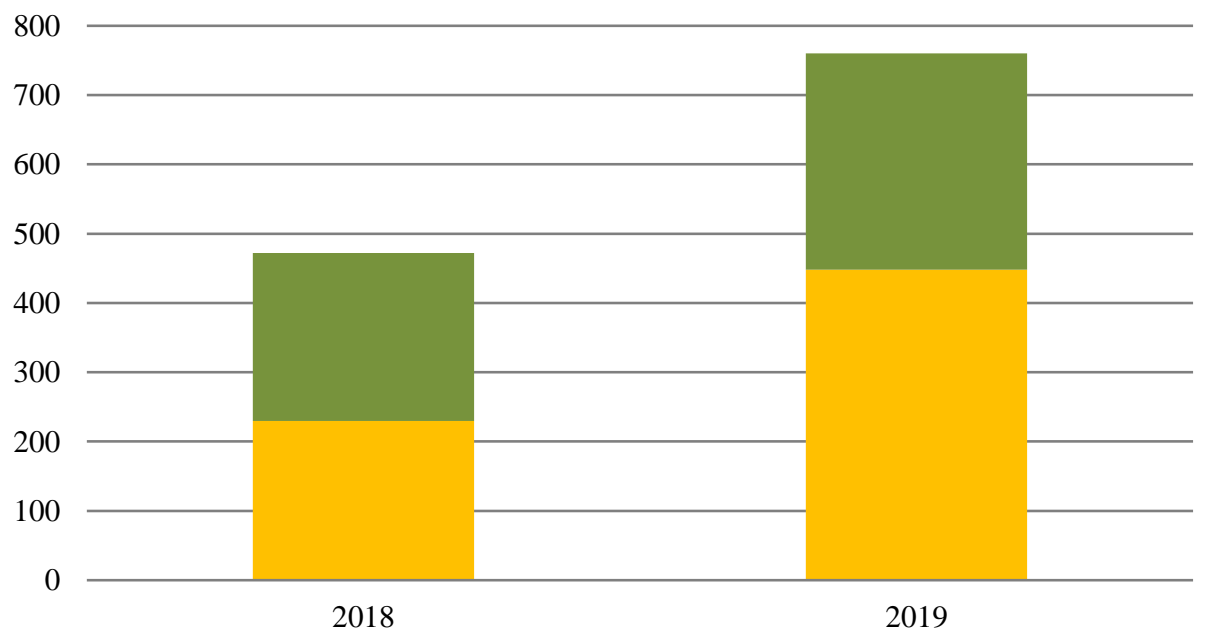

podatek minimalny odliczony od CIT $\quad$ podatek minimalny nieodliczony od CIT

Wykres 1. Wysokość podatku minimalnego w rozliczeniach za 2018 i 2019 r. (w mln zł)

Źródło: opracowanie własne na podstawie baz danych Ministerstwa Finansów.

${ }^{3}$ Prawdopodobnie część podatników „nieprofesjonalnych” takich jak wspólnoty mieszkaniowe, błędnie wykazała należności z tytułu tego podatku. 
Tabela 1. Statystyki dotyczące minimalnego podatku od nieruchomości komercyjnych

\begin{tabular}{|c|c|c|c|c|c|c|}
\hline \multirow{2}{*}{ Rok } & \multicolumn{4}{|c|}{ Podatek minimalny od nieruchomości komerycjnych (art. 24b ustawy CIT) } \\
\cline { 2 - 7 } & \multicolumn{3}{|c|}{ Podatek obliczony } & \multicolumn{2}{c|}{$\begin{array}{c}\text { Nadwyżka podatku minimalnego nad } \\
\text { podatkiem CIT wyliczonym na } \\
\text { zasadach ogólnych }\end{array}$} \\
\cline { 2 - 7 } & $\begin{array}{c}\text { Liczba po- } \\
\text { datników }\end{array}$ & $\begin{array}{c}\text { Kwota po- } \\
\text { datku w tys. } \\
\text { zł }\end{array}$ & $\begin{array}{c}\text { Przeciętny } \\
\text { podatek } \\
\text { w tys. zł }\end{array}$ & $\begin{array}{c}\text { Liczba po- } \\
\text { datników }\end{array}$ & $\begin{array}{c}\text { Kwota } \\
\text { podatku } \\
\text { w tys. zł }\end{array}$ & $\begin{array}{c}\text { Przeciętny po- } \\
\text { datek w tys. zł }\end{array}$ \\
\hline 2018 & 2591 & 472204 & 182 & 938 & 241766 & 258 \\
\hline 2019 & 3551 & 760756 & 214 & 1334 & 312490 & 234 \\
\hline $2019 / 2018$ & $137 \%$ & $161 \%$ & $118 \%$ & $142 \%$ & $129 \%$ & $91 \%$ \\
\hline
\end{tabular}

Źródło: opracowanie własne na podstawie materiałów Ministerstwa Finansów.

Podatek od przychodu ze środka trwałego będącego budynkiem został w 2018 r. wykazany przez podatników na łączną kwotę $472 \mathrm{mln}$ zł, a w 2019 r. na $761 \mathrm{mln}$ zł. Podatek od przychodów z budynków powinien być w założeniu dla większości podatników neutralny, co wynika z możliwości odliczenia należnego podatku od przychodów z budynków od podatku CIT wyliczonego na zasadach ogólnych. Część podatników nie wykazała jednak na tyle dużego podatku CIT aby odliczyć od niego w całości należny podatek od przychodów z budynków. W 2018 r. sytuacja ta dotyczyła 36,2\% podatników (938 na 2 591), natomiast w 2019 r. 37,6\% podatników (1 334 na 3 551). Pomimo wzrostu liczby podatników podatku od przychodów z budynków o $37 \%$ z roku na rok, proporcja ta pozostała na podobnym poziomie. Nadwyżkę podatku minimalnego od nieruchomości komercyjnych nad podatkiem CIT obliczonym na zasadach ogólnych 938 podatników wykazało w 2018 r. na łączną kwotę $242 \mathrm{mln}$ zl, natomiast w $2019 \mathrm{r}$. 1334 podatników na łączną kwotę $312 \mathrm{mln}$ zł. W ujęciu kwotowym oznaczało to, że w $2018 \mathrm{r}$. aż 52\% należnego podatku minimalnego nie podlegało odliczeniu od podatku CIT obliczonego na zasadach ogólnych (242 na $472 \mathrm{mln}$ zł), a w $2019 \mathrm{r}$. już nieco mniej - 41\% (312 na $761 \mathrm{mln}$ zł), co przedstawiono na wykresie 1 . Wskazuje to, że około $1 / 3$ podatników poniosła ekonomiczny ciężar podatku odpowiadający ok. 40-50\% wpływów z tytułu tego podatku ogółem. Dla części podatników stanowi to jedynie przejściowe obciążenie, gdyż w odpowiedniej procedurze można uzyskać zwrot podatku minimalnego zapłaconego i nieodliczonego od CIT.

W stosunku do 2018 r. należny podatek od przychodów z budynków wzrósł w 2019 r. znacząco, bo aż o $61 \%$. Dotyczy to także wzrostu o $18 \%$ r/r przeciętnego należnego podatku od nieruchomości komercyjnych. Wzrost wynikał przede wszystkim ze zmian legislacyjnych, w tym w szczególności poszerzenia przedmiotowego zakresu ustawy oraz odniesienia kwoty wolnej do wszystkich nieruchomości podatnika, a nie do każdej odrębnie. Przeciętna nadwyżka podatku od 
przychodów z budynków nad należnym podatkiem CIT była jednak o $9 \%$ niższa w 2019 r. niż w roku poprzednim. Wiązać to można ze wzrostem średniej kwoty podatku CIT obliczonego na zasadach ogólnych przez podatników podatku minimalnego. Kwota należnego podatku dochodowego wykazana na zasadach ogólnych w 2018 r. wśród tych podatników wynosiła bowiem 1,9 mln złotych a w kolejnym roku już 3,2 mln złotych, więc o $68 \%$ więcej (zob. tabela 1 ). Wyższe dochody do opodatkowania na zasadach ogólnych w 2019 r. pozwoliły podatnikom podatku minimalnego od nieruchomości komercyjnych w większym stopniu skorzystać z możliwości odliczenia tego podatku od podatku CIT.

Wśród podatników podatku minimalnego od nieruchomości komercyjnych pojawiają się podatnicy o różnych formach prawnych, jednak pod względem należnego podatku minimalnego podmioty nieprowadzące zasadniczo działalności gospodarczej (np. wspólnoty mieszkaniowe czy stowarzyszenia) miały marginalne znacznie, odpowiadając jedynie za ok. 1\% tego podatku. Za 90\% wykazanego podatku minimalnego odpowiadały spółki z o.o. i spółki akcyjne, więc na tych podmiotach spoczywał faktyczny ciężar tej nowej w polskim systemie podatkowym daniny. Podatek minimalny od nieruchomości komercyjnych dotyczy także podatników PIT. Mają oni jednak relatywnie niewielkie znaczenie, odpowiadając jedynie za 7\% podatku minimalnego w ujęciu łącznym (PIT i CIT).

\section{OCENA POLSKIEGO ROZWIAZZANIA}

Przedmiotem opodatkowania podatkiem dochodowym jest dochód. Z pozoru oczywista konkluzja rodzi jednak w praktyce szereg wątpliwości, ponieważ wyrażony ustawowo system podatku dochodowego kreuje jedynie pewną aproksymację dochodu. Czasami zdarza się, że podatnik faktycznie nie osiąga dochodu, pomimo czego dochód jest rozpoznawany na gruncie ustaw podatkowych. Może się tak zdarzyć na przykład w konsekwencji zastosowania memoriałowej zasady rozpoznawania przychodów, czy też niemożności uwzględnienia w kosztach podatkowych pewnych wydatków. Znacznie częściej zdarza się jednak tak, że pomimo osiągnięcia faktycznych dochodów, dochody te pozostają nieopodatkowane. Sytuacja ta może wynikać z zaplanowanego przez ustawodawcę systemu ulg i zwolnień, czy systemowego pominięcia niezrealizowanych zysków, ale często wynika z szeroko pojętego unikania opodatkowania. Faktyczna podstawa opodatkowania odbiega od koncepcji dochodu najczęściej w przypadku podmiotów działających międzynarodowo i wykorzystujących dodatkowo różnice pomiędzy zasadami (i szczegółami) opodatkowania dochodu w różnych jurysdykcjach.

$\mathrm{W}$ tym stanie rzeczy uzasadnienie znajduje poszukiwanie rozwiązań przeciwdziałających unikaniu opodatkowania, w tym w szczególności regulacji antyabuzywnych. Mają one na celu zbliżenie wielkości deklarowanego dochodu do 
opodatkowania do dochodu rzeczywiście wypracowanego przez podatników. Regulacje antyabuzywne wynikają wprost z konieczności zapewnienia sprawiedliwości podatkowej. Charakter minimalnego podatku dochodowego przypisać można wielu regulacjom antyabuzywnym. W istocie nie chodzi tu o kreowanie dodatkowych zobowiązań podatkowych, ale zapobieżenie zbytniemu oderwaniu dochodu do opodatkowania od faktycznie osiąganego dochodu w danej jurysdykcji. Zastosowanie ograniczeń w zaliczaniu do kosztów podatkowych kosztów finansowania dłużnego czy usług niematerialnych, rozciągnięcie opodatkowania na kontrolowane spółki zagraniczne, zastosowanie regulacji przeciwdziałających rozbieżnościom w kwalifikacji struktur hybrydowych i wiele innych podobnych regulacji prowadzi do zwiększenia podstawy opodatkowania do pewnego arbitralnego „minimalnego” poziomu opodatkowania. Zjawisko to jest wyraźniej widoczne w przypadku konstrukcji podatku od przychodów z nieruchomości komercyjnych, dlatego mechanizm taki nazywany jest minimalnym podatkiem od przychodów $\mathrm{z}$ budynków, jednak w istocie jego charakter nie odbiega od innych regulacji antyabuzywnych. $Z$ uwagi na możliwość ubiegania się o zwrot zapłaconego podatku od przychodów z budynków, miano „minimalnego” jest wręcz nieuprawnione, a przynajmniej w mniejszym stopniu, niż na przykład w przypadku ograniczeń potrącalności odsetek lub kosztów usług niematerialnych, gdzie wyłączenie odsetek z kosztów uzyskania przychodów może mieć charakter trwały i faktycznie kreować podatek minimalny.

Oderwanie faktycznie osiąganych dochodów w Polsce od dochodu wykazanego do opodatkowania jest szczególnie widoczne w przypadku podatników, którzy posiadają aktywa znacznej wartości i oddają je do korzystania podmiotom trzecim za wynagrodzeniem, a jednocześnie nie wykazują dochodów do opodatkowania lub wykazują go na niewspółmiernie niskim poziomie. Konkurencyjność rynku wynajmu nieruchomości komercyjnych, pewna standaryzacja i porównywalność danych statystycznych dotyczących tego rynku pozwala w miarę obiektywnie określić przedziały zwrotu z zainwestowanego kapitału. Uśrednione wartości zwrotu osiąganego $\mathrm{w}$ sektorze $\mathrm{z}$ tytułu oddania do korzystania nieruchomości komercyjnych ${ }^{4}$ można porównać $\mathrm{z}$ założeniami przyjętymi przez ustawodawcę. Skoro stawka podatku wynosi $0,035 \%$ podstawy opodatkowania (wartości początkowej aktywów) za każdy miesiąc, oznacza to, że ustawodawca założył minimalny zwrot $\mathrm{z}$ inwestycji w wysokości około $2 \%(0,035 \% * 12 / 19 \%)$ rocznie. Relatywnie niski poziom założonego przez ustawodawcę minimalnego dochodu z oddawania do korzystania nieruchomości komercyjnych w połączeniu z szeregiem rozwiązań zabezpieczających neutralność tego podatku (możliwość ubiegania się o zwrot wpłaconych kwot, wysoka kwota wolna, ograniczenie do części

${ }^{4}$ Aspekt ten wymaga odrębnej dodatkowej analizy średich wartości zwrotów osiąganych w sektorze. 
nieruchomości faktycznie oddanej do korzystania itp.) sprawia, że rozwiązanie to można ocenić jako adekwatny i nienadmiarowy środek antyabuzywny.

Objęcie podatkiem minimalnym od nieruchomości komercyjnych różnych kategorii podatników CIT, którzy nie prowadzą działalności gospodarczej, w tym przede wszystkim wspólnot i spółdzielni mieszkaniowych, fundacji, stowarzyszeń, związków zawodowych, gminnych ośrodków kultury, SPZOZ, uczelni, czy cechów rzemieślniczych nie znajduje jednak mocnego uzasadnienia. Oczywiście podmioty te mogą ubiegać się o zwrot podatku, jednak nakładanie obowiązków związanych z rozliczaniem podatku minimalnego od przychodów z budynków rodzi wątpliwości. Wartym rozważenia jest także wyłączenie z zakresu podmiotowego podatku minimalnego podatników, dla których wynajem nieruchomości jest jedynie działalnością poboczną, uzupełniającą. Cel ten można osiągnąć poprzez dodanie do ustawy warunków zwalniających z obowiązku rozliczania podatku np. w przypadku gdy udział przychodów z nieruchomości jest marginalny w stosunku do przychodów z działalności podstawowej. Podobnie, należy rozważyć zrewidowanie zasadności obciążania rozliczeniami związanymi z podatkami minimalnym od przychodów z budynków podmiotów obsługujących infrastrukturę publiczną. Zwolnienie od podatku od przychodów $\mathrm{z}$ budynków mogłoby dotyczyć w tym wypadku przychodów ze środka trwałego będącego budynkiem stanowiącym część infrastruktury publicznej (np. dworzec, czy port lotniczy). Tego typu wyłączenie z opodatkowania podatkiem minimalnym budynków wykorzystywanych $\mathrm{w}$ interesie publicznym nie rodzi większego ryzyka z punktu widzenia erozji bazy opodatkowania i transferu zysków, a także znajduje uzasadnienie w kontekście prawa Unii Europejskiej.

\section{PODSUMOWANIE}

Przedstawiona analiza prowadzi do konkluzji, że zastosowanie w porządku krajowym rozwiązania antyabuzywnego, takiego jak minimalny podatek od przychodów z budynków, należy uznać za uzasadnione. Konstrukcja podatku minimalnego obliguje podatników wykazujących straty podatkowe bądź niski dochód podatkowy do uiszczania podatku od przychodów z budynków. W założeniu zwrot podatku od przychodów z budynków ma przysługiwać podatnikom, których strata albo niski dochód do opodatkowania nie wynika z przerzucania zysków (dochodów), w szczególności w wyniku stosowania nierynkowych cen transferowych.

Niski poziom założonego przez ustawodawcę minimalnego dochodu z oddawania do korzystania nieruchomości komercyjnych w połączeniu z rozwiązaniami zabezpieczającymi neutralność tego podatku sprawia, że rozwiązanie to należy ocenić jako adekwatny środek antyabuzywny. Zweryfikowano również 
pozytywnie hipotezę, że podatek minimalny $\mathrm{w}$ formie podatku od przychodów z budynków jest nienadmiarowym środkiem antyabuzywnym.

Do dalszej analizy ewaluacyjnej pozostaje możliwość osiągnięcia podobnego rezultatu bez konieczności obarczania obowiązkami związanymi z rozliczeniami podatkowymi przedsiębiorców, dla których wynajem nieruchomości komercyjnych stanowi jedynie marginalną lub uboczną sferę działalności. Wartym rozważenia jest w szczególności wprowadzenie możliwości zwolnienia przedsiębiorcy z obowiązku rozliczenia podatku minimalnego od nieruchomości komercyjnych, jeżeli w poprzednim roku podatkowym przychody z budynków stanowiły jedynie niewielki odsetek osiąganych przez niego przychodów.

\section{BIBLIOGRAFIA}

Banasik, P., Kałążny, A., Morawski, W. (2018). Podatek od przychodu z budynków - następca minimalnego podatku dochodowego od wartości budynków komercyjnych. W: B. Brzeziński, K. Lasiński-Sulecki, W. Morawski, red., Nowe narzędzia prawne w podatkach dochodowych i majatkowych. Poprawa efektywności systemu podatkowego. Monografie LEX.

Interpretacja indywidualna DKIS $\mathrm{z}$ dnia 11 marca 2019 r., $\quad$ sygn. 0111-KDIB21.4010.512.2018.1.MJ.

Ministerstwo Finansów, 6 kwietnia 2018 r., Ustalenia z KE ws. minimalnego podatku dochodowego od nieruchomości komercyjnych, https://mf-arch2.mf.gov.pl/en/ministerstwo-finansow/wiadomosci/komunikaty/-/asset_publisher/6Wwm/content/ustalenia-z-ke-ws-minimalnego-podatku-dochodowego-od-nieruchomosci-komercyjnych/pop_up?_101_IN-

STANCE_6Wwm_viewMode=print [dostęp: 4.01.2021].

OECD/G20, October 14, 2020, Tax Challenges Arising from Digitalisation - Report on Pillar Two Blueprint, Inclusive Framework on BEPS, http://www.oecd.org/tax/beps/tax-challenges-arising-from-digitalisation-report-on-pillar-two-blueprint-abb4c3d1-en.htm [dostęp: 4.01.2021].

Shaviro, D. (2020). What are minimum taxes, and why might one favor or disfavor them?. NYU Law and Economics Research Paper, 20-38.

Ustawa z dnia 15 czerwca 2018 r. o zmianie ustawy o podatku dochodowym od osób fizycznych, ustawy o podatku dochodowym od osób prawnych oraz ustawy o zryczałtowanym podatku dochodowym od niektórych przychodów osiąganych przez osoby fizyczne, Dz.U. 2018, poz. 1291.

Ustawa z dnia 15 lutego 1992 r. o podatku dochodowym od osób prawnych, tj. Dz.U. 2020, poz. 1406.

Ustawa z dnia 26 lipca 1991 r. o podatku dochodowym od osób fizycznych, tj. Dz.U. 2020, poz. 1426.

Ustawa z dnia 27 października 2017 r. o zmianie ustawy o podatku dochodowym od osób fizycznych, ustawy o podatku dochodowym od osób prawnych oraz ustawy o zryczałtowanym podatku dochodowym od niektórych przychodów osiąganych przez osoby fizyczne, Dz.U. 2017, poz. 2175.

Uzasadnienie do rządowego projektu ustawy o zmianie ustawy o podatku dochodowym od osób fizycznych, ustawy o podatku dochodowym od osób prawnych oraz ustawy o zryczałtowanym podatku dochodowym od niektórych przychodów osiąganych przez osoby fizyczne, druk nr 1878. 


\section{DOŚWIADCZENIA POLSKIE W MINIMALNYM OPODATKOWANIU: PODATEK OD PRZYCHODÓW Z BUDYNKÓW}

\section{Streszczenie}

Cel artykułu/hipoteza. Celem artykułu jest przedstawienie koncepcji podatku minimalnego od nieruchomości komercyjnych oraz dokonanie oceny wprowadzonej regulacji, w tym sformułowanie postulatów de lege ferenda.

Metodyka. Przenalizowana została ewolucja regulacyjna tego podatku w latach 2018-2020 oraz jej wpływ na rozliczenia podatników z tego tytułu.

Wyniki/Rezultaty badania. Podatek ten ma w szczególności zapobiegać unikaniu opodatkowania poprzez niewykazywanie dochodu przez duże spółki nieruchomościowe, posiadające nieruchomości komercyjne o znacznej wartości. Podatkiem minimalnym od nieruchomości komercyjnych objęty został niecały $1 \%$ wszystkich podatników CIT. Około $1 / 3$ podatników nie odliczyła w pełni należnego podatku minimalnego od nieruchomości komercyjnych od podatku CIT obliczonego na zasadach ogólnych. Efekt zwiększonego obciążenia podatkowego, przynajmniej przejściowego, był dość znaczący dla tej grupy podatników. Zdaniem autorów, szereg rozwiązań zabezpieczających neutralność tego podatku sprawia, że rozwiązanie to należy ocenić zasadniczo jako adekwatny i w większości przypadków nienadmiarowy środek antyabuzywny.

Słowa kluczowe: podatek minimalny, opodatkowanie przychodów, budynki komercyjne, unikanie opodatkowania, CIT. 